\title{
THE PROBLEM OF REBEDDED POLLEN IN LATE-GLACIAL SEDIMENTS AT TAUNTON, MASSACHUSETTS
}

\author{
MARGARET B. DAVIS* \\ California Institute of Technology, Pasadena, California
}

\begin{abstract}
The occurrence of pollen of tree genera not found in the modern flora of the United States and Canada in late-glacial sediments from the Williams Street bog near Taunton, Massachusetts, is considered evidence of contamination of the sediments with secondary pollen rebedded from pre-Quaternary deposits. Nearby varved clays also contain these pollen types, and because the local till contains little if any pollen, it is concluded that the secondary pollen was carried in glacial meltwater from the vicinity of Tertiary deposits 25 miles to the northeast. The late-glacial bog sediments were apparently contaminated either directly by meltwater streams, or through the erosion and redeposition of meltwater stream deposits. As the secondary pollen spectrum cannot be determined with certainty, it is impossible to interpret the mixed secondary and primary pollen spectrum contained in the late-glacial sediments.
\end{abstract}

\section{INTRODUCTION}

American pollen analysts have recently become concerned with a serious source of error in pollen analysis, the contamination of deposits with pollen from older sediments. Pollen grains are sometimes able to undergo more than one cycle of deposition without perceptible change in morphology; thus a single stratum may contain morphologically similar pollen grains derived from plants widely separated in time. Unless the rebedded or "secondary" pollen is distinguished from "primary" pollen derived from vegetation living at the time the sediments were deposited, its occurrence in sediments may lead the pollen analyst to erroneous interpretations of vegetational history.

The presence of rebedded pollen in late-glacial deposits in Denmark was demonstrated by Iversen (1936). He found that boulder-clay and varved clay in the vicinity of contaminated deposits contained pollen and other microfossils from Tertiary sediments that had been over-ridden and eroded by the ice sheet. The late-glacial minerogenic sediments were contaminated with a similar assemblage of pollen but contained in addition pollen derived from the lateglacial vegetation. Iversen showed that, if the spectrum of secondary pollen was determined from samples of nearby boulder-clay or varved clay, it could be subtracted mathematically from late-glacial pollen spectra. Vegetational history could then be studied as it was recorded by the primary pollen.

Secondary microfossils in glacial drift have also been reported in this country. Mather, Goldthwait, and Thiesmeyer (1942) and Sayles and Knox (1943) concluded that microfossils in tills and glacial silty clays on Cape Cod, 25-50 miles east-southeast of Taunton, were derived from interstadial or interglacial marine deposits that had been over-ridden and eroded by glacial ice.

Recently most pollen investigators working with inorganic late- and postglacial sediments in America have considered the possibility that the sediments were contaminated with rebedded pollen. In most cases the criterion for suspecting contamination was the occurrence, in the same strata, of pollen grains from genera and species that are apparently ecologically incompatible * Now at Department of Botany, University of Michigan, Ann Arbor, Michigan. 
in the present vegetation. In two instances (Andersen, 1954; Martin, 1958) pollen types which conflicted with vegetational and climatic interpretations based on the majority of the pollen in clays and sandy sediments, and which were therefore considered secondary, were subtracted from the pollen sum, and "corrected" pollen diagrams were published. In other cases (Leopold, 1956; Livingstone and Livingstone, 1958; Davis, 1958; Ogden, 1959), pollen types for which a secondary origin was suspected were plotted on the diagrams but given less weight in the vegetational and climatic interpretation than other pollen types. In no instance, however, was the investigator able to demonstrate the source of the putative rebedded pollen, or to employ the objective subtraction method of Iversen (1936).

In the course of analyzing the pollen in a core from a bog near Taunton, Massachusetts, the author found evidence of contamination of the late-glacial sediments with pollen rebedded from pre-Quaternary deposits. This paper reports this evidence and presents the results of an investigation of the possible sources for rebedded pollen at Taunton. The problems of estimating the extent of contamination and of interpreting pollen analyses of contaminated sediments are discussed.

\section{ACKNOWLEDGMENTS}

I acknowledge with gratitude the many helpful suggestions and criticisms of Joseph H. Hartshorn and John P. Schafer. John C. Goodlett, Daniel A. Livingstone and Estella B. Leopold also provided valuable criticism of an earlier version of the manuscript. The work was done at the Biology Department, Harvard University, and at the Geology Division, California Institute of Technology; it was supported by NSF fellowships 47035 and 40002 and research grant (to E. S. Deevey) G-4802. This paper is Contribution 979 of the Division of Geological Sciences, California Institute of Technology.

\section{EVIDENCE OF REBEDDED POLLEN}

The pollen diagram from the Williams Street bog near Taunton, Massachusetts (Davis, 1960) is similar in its major features to pollen diagrams from other parts of southern New England (Leopold, 1955; Leopold and Scott, 1958; Davis, 1958). It appears to record the development of forest during the Two Creeks interstadial (pollen zones $\mathrm{T}$ and $\mathrm{A}-1-2-3$ ), the decline in frequency of pine and deciduous trees relative to spruce during the Valders stadial (zone A-4), and the subsequent decline of spruce and increase in the frequency of pine and deciduous trees (zone B). (The upper levels of the deposit, in which deciduous tree pollen is presumably abundant, were not analyzed because of poor pollen preservation.) The stratigraphy of the core is as follows:

0-2.77 $\mathrm{m}$ Brown peat with wood and moss fragments. Loss on ignition 98-99\% dry weight (2 samples). Pollen zone C (presumably).

2.77-2.86 $\mathrm{m}$ Coarse fibrous peat with grasslike leaf fragments. Loss on ignition 97\% (1 sample). Zone B-2.

2.86-3.43 m Very fine fibrous peat. Loss on ignition $52.83 \%$ (2 samples). Zone B-2.

3.43-3.62 m Very fine fibrous peat grading to gyttja. Loss on ignition $30 \%$ (1 sample). Zone B-1. 
3.62-4.00 m Cray-green gyttja. Loss on ignition 19-22\% (5 samples). Zone A-4.

4.00-4.41 m Green-brown gyttja. Loss on ignition 22-29\% (5 samples). Zone A-1-2-3.

4.41-4.47 m Fibrous peat with grass-like leaf fragments. Loss on ignition $25 \%$ ( 1 sample). Zone A-1-2-3.

4.47-4.95 m Gray silty sand streaked with dark gray sand. Sand at $4.80 \mathrm{~m}$. Loss on ignition $2.4 \%$ (6 samples). Zone T?.

4.95-5.20 m Medium coarse sand. Loss on ignition $1-2 \%$ (5 samples). Zone $\mathrm{T}$ ?. It was not possible to penetrate deeper with the Hiller borer.

A major difference between this diagram and others in southern New England is the occurrence, in the lower levels of the deposit, of pollen of genera that are not found in the modern flora of the United States. Pollen of Platycarya, a genus now limited to Asia. was found at 4.52, 4.85, 4.95, 5.05 (2 grains), 5.15 (7 grains), and $5.20 \mathrm{~m}(8$ grains) ; Pterocarya, also limited to Asia, at $5.10 \mathrm{~m}$ (1 grain); and Engelhardtia-Alfaroa, limited to Asia and Central America, and to Central America. respectively, at 4.80, 5.05 (3 grains), 5.15 (2 grains) and $5.20 \mathrm{~m}$ (8 grains). Platycarya, Pterocarya, and Engelhardtia have all been reported from Tertiary deposits in this country, and Pterocarya has also been reported from the Pleistocene of Maryland (LaMotte, 1952; Leopold and Scott, ms.). As these genera do not occur in the modern flora, and are not recorded in the postglacial fossil record, it seems improbable that they grew in the vicinity of Taunton at the time of the retreat of the ice. A far more plausible explanation is that their pollen has been rebedded from Tertiary deposits. If this is so, Tertiary pollen types that are indistinguishable from the pollen of modern species may also be rebedded in the sediments in which these pollen types occur. The presence of primary pollen as well is implied by the general similarity of the pollen spectra at these levels to pollen zone $\mathrm{T}$ at other sites.

To subtract secondary pollen from a mixed spectrum of primary and secondary pollen, it is necessary to know the complete spectrum either of the primary pollen or of the secondary pollen. As the purpose of the original investigation was to discover the primary pollen spectrum, no assumptions as to its nature are justified. It may be possible, however, to determine the secondary pollen spectrum from older pollen-bearing sediments in the vicinity, or from till or glacial clay deposited by a glacier that had eroded such sediments. Because the secondary pollen may have been derived from several different deposits, analyses of older sediments in the vicinity may not include all the secondary pollen types, nor represent them in the proper proportions. In any event, older pollen-bearing sediments (other than varved clay) are not known in the Taunton quadrangle (Emerson, 1917). Difficulties may also be encountered in attempts to recover the secondary pollen spectrum from glacial deposits. Iversen (1936) found identical pollen spectra in till and glacial clay in Denmark and concluded that all the pollen in both types of deposit was secondary. This implies that plants did not live within pollen dispersal distance when the ice was active and when the rarred clay was deposited. It cannot be 
assumed that this was true in Massachusetts, as late-glacial pollen diagrams record a comparatively rapid immigration of trees onto the newly deglaciated landscape. Thus supraglacial till and glacial clay in this region may contain primary as well as secondary pollen. ${ }^{1}$

In an attempt to determine the spectrum of secondary pollen rebedded in the Williams Street bog sediments, samples of nearby ground moraine, flowtill and varved clay were analyzed for their pollen content.

\section{POLLEN ANALYSIS OF TILL}

Four samples of unweathered till were collected from borrow pits and building excavations in the vicinity of the Williams Street bog. The locations of the collections are shown in figure 1. Samples A and B are flowtill, ablation moraine which slid as a mudflow from the surface of glacial ice onto stratified sand and gravel (Hartshorn, 1958). Samples C and D are ground moraine and contain abundant stones of the local bedrock. ${ }^{2}$

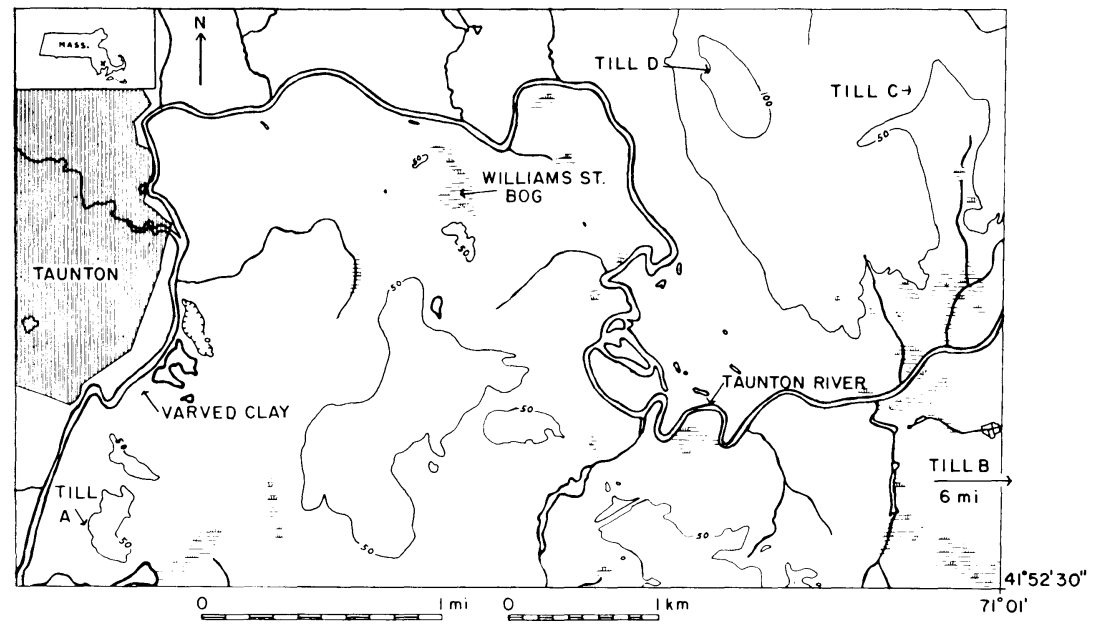

Fig. 1. Outline map of a portion of the Taunton quadrangle, showing locations at which samples were collected. Contour interval $50 \mathrm{ft}$, datum mean sealevel. Inset shows approximate location in state of Massachusetts. Drawn from U. S. Geological Survey topographic map, $1: 24000$, revised 1949.

The samples were treated in the laboratory with $\mathrm{HF}$ and $\mathrm{HCl}$, as recommended by Heinonen (1957). Bromoform flotation (Frey, 1951) was also used as a final step to remove the precipitate which formed in hydrofluoric acid. No pollen grains were found in samples B and D, although 1 grain (Fraxinus-type) was found in an empty tube put through the extraction procedure as a control for contamination at the same time that sample B was prepared. Three grains were found in sample C: 1 Fraxinus-type, 1 Ambrosia, and 1 Pinus. Unfortunately no control was run on the day this sample was

1 The occurrence of leaf and seed fossils of arctic-alpine plants in varved clay in the Connecticut Valley, Massachusetts (Emerson, 1898) further indicates that varved clay may contain primary pollen.

2 I am grateful to J. P. Schafer for sending me till samples B, C and D. 
prepared, but the occurrence of pollen in a previous control suggests that the sample was originally devoid of pollen. By contrast, Heinonen (1957), using much the same laboratory method and the same size samples, was able to extract from 0-9,340 tree pollen, 0-3,340 herb pollen, and 0-980 spores from samples of basal till from Finland. A few pollen and spores were extracted from sample A by means of repeated bromoform flotation of fines washed from a $600 \mathrm{gm}$ sample. Heinonen (1957) has shown that this method is much less effective than $\mathrm{HF}$ for extraction of pollen from till, because most of the pollen occurs in a crust of fine particles adhering to the larger stones. A further disadvantage to the method is the increased possibility of contamination, as large amounts of reagents are used and the large sample is exposed to air for the several hours required for the procedure. Fifteen pollen and spores were found in sample A: 3 Ambrosia, 3 Betula, 1 Compositae, 1 Fraxinus, 1 Pinus, 1 unknown, 1 Lycopodium, and 4 fern spores. Lnfortunately no control was run at the time the sample was prepared, but when a control was put through the same procedure some months later, 6 pollen grains were found. It seems likely that most of the pollen grains and spores found in this sample also represent laboratory contamination.

Even if it is assumed that the till samples contain pollen in addition to laboratory contamination, the numbers of grains are so low that it seems unlikely that either the till or the glacial ice from which it originated could have served as a principal source of secondary pollen. In any event, pollen of Platycarya, Pterocarya, and Engelhardtia-Alfaroa would be unexpected in the till, because the nearest known Tertiary sediments from which the pollen might have been derived are located approximately 25 miles to the northeast (Emerson, 1917). Tertiary pollen would occur in the ground moraine at Taunton only if ice had eroded these sediments and subsequently flowed 25 miles to the southwest. The general direction of glacial flow was apparently not toward Taunton, however, but to the southeast (Flint and others, 1959).

\section{POLLEN ANALYSIS OF YARVED CLAY}

In contrast to the till, varved clay from the Taunton quadrangle contains abundant pollen. Samples were collected from the south wall of a claypit just east of the Taunton River (fig. 1). Sample E was collected about $8 \mathrm{ft}$ below the surface of the clay, $3 \mathrm{ft}$ below an unconformity between gray varved clay and overlying brown oxidized clay, sample $F$ from a thick varve $1 \mathrm{ft}$ lower in the section, and sample $G$ about $50 \mathrm{ft}$ further west, $2 \mathrm{ft}$ below a thick varve believed to be the same as that from which sample $\mathrm{F}$ was collected. Pollen was extracted without difficulty by flotation in bromoform, boiling in $10 \%$ $\mathrm{KOH}$, and acetolysis, and was stained and mounted in glycerin. About 350 pollen and spores were counted from each sample. It is assumed that laboratory contamination was not significant; if any occurred it would represent only a small proportion of the abundant pollen extracted from each sample.

Over fifty different pollen types were found in the varved clay. The percentages are shown in table 1. (For comparison, the table also shows the pollen spectrum from $5.20 \mathrm{~m}$ depth in the bog sediments.) The percentages of pollen in the three clay samples appear similar, but not identical. Differences in per- 
TABLE 1

Pollen percentages in varved clay samples, and sample from $5.20 \mathrm{~m}$ level at Williams Street bog

\begin{tabular}{|c|c|c|c|c|}
\hline \multirow[t]{2}{*}{ Pollen or spore type } & \multicolumn{4}{|c|}{ Percentage in sample } \\
\hline & $\mathrm{E}$ & $\underset{\mathrm{F}}{\text { Varvec }}$ & G & $\begin{array}{c}\text { Bog sediment } \\
5.20 \mathrm{~m}\end{array}$ \\
\hline Abies & 1.9 & 0.3 & 0.3 & 0.1 \\
\hline 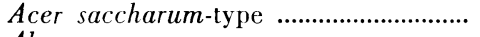 & - & 0.3 & - & - \\
\hline Alnus & 4.0 & 1.4 & 2.6 & 4.7 \\
\hline 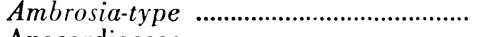 & $\overline{0}-$ & - & 0.3 & 0.4 \\
\hline Anacardiaceae & $0 . \overline{5}$ & - & 0.5 & 0.6 \\
\hline 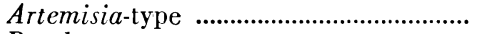 & 0.5 & 1.4 & 0.5 & 0.8 \\
\hline 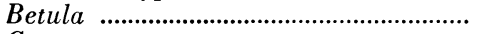 & $11 . \overline{7}$ & 23.1 & 27.6 & 6.1 \\
\hline Carya & 5.3 & 2.2 & 1.8 & - \\
\hline 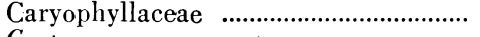 & - & - & - & 0.7 \\
\hline 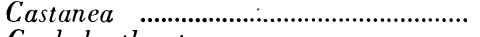 & 3.5 & - & 2.9 & 2.0 \\
\hline 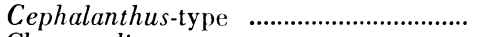 & 1.3 & 0.6 & 0.5 & 0.3 \\
\hline 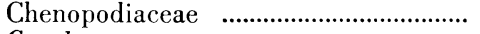 & - & - & 0.5 & 0.1 \\
\hline 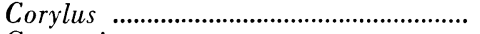 & 4.0 & 1.7 & 2.9 & 1.5 \\
\hline 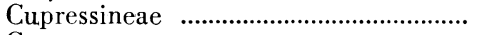 & 2.4 & 1.4 & 0.5 & 0.2 \\
\hline Cyperaceae & 0.5 & 2.8 & 0.5 & 19.7 \\
\hline Engelhardtia ............................................... & 1.3 & - & - & 1.0 \\
\hline 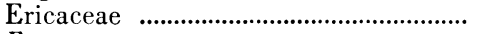 & - & 1.1 & 0.5 & 2.0 \\
\hline 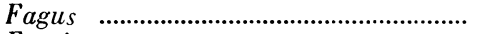 & - & 0.3 & 0.5 & - \\
\hline 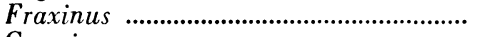 & 2.7 & 1.7 & 1.3 & 1.3 \\
\hline 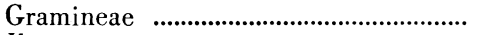 & 2.9 & 2.5 & 1.8 & 6.9 \\
\hline Ilex & 0.3 & 0.3 & 0.3 & - \\
\hline Leguminosae? & - & 0.3 & 0.3 & - \\
\hline 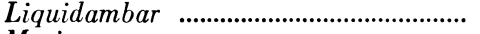 & - & 0.3 & - & - \\
\hline 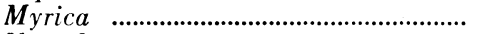 & 0.3 & 0.6 & 0.3 & 0.8 \\
\hline 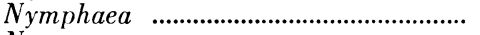 & 0.3 & - & - & - \\
\hline Nyssa & 3.5 & 5.0 & 4.2 & 0.8 \\
\hline 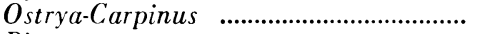 & 1.1 & 0.3 & 0.5 & 0.3 \\
\hline Picea & $0 . \overline{5}$ & 1.9 & 1.0 & 3.8 \\
\hline Pinus & 8.5 & 8.1 & 12.2 & 29.2 \\
\hline 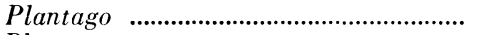 & - & - & - & 0.1 \\
\hline 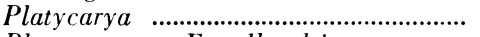 & 2.4 & 0.3 & 0.3 & 0.9 \\
\hline Platycary $a$ or Engelhardtia ...................... & 0.5 & - & - & - \\
\hline 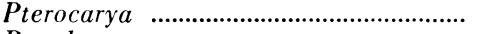 & 0.3 & - & - & - \\
\hline 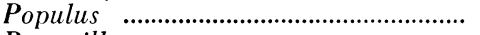 & 0.5 & 0.8 & 1.0 & - \\
\hline 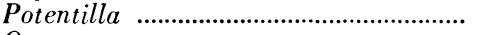 & - & - & - & 0.1 \\
\hline 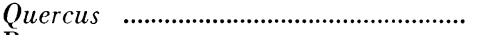 & 6.6 & 12.5 & 16.7 & 1.8 \\
\hline 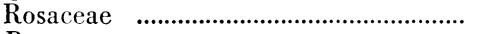 & - & 0.3 & 0.3 & 0.1 \\
\hline 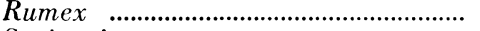 & - & - & - & 0.1 \\
\hline Sagittaria-type & 0.3 & - & - & - \\
\hline 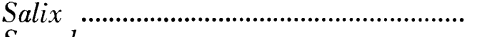 & - & 2.5 & 0.8 & 3.9 \\
\hline Symplocos & - & 0.6 & 0.8 & - \\
\hline 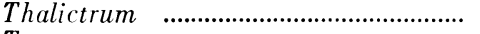 & - & - & - & 0.9 \\
\hline 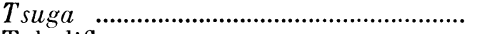 & 0.3 & 0.6 & 0.3 & - \\
\hline 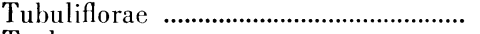 & 1.3 & - & 1.8 & 1.2 \\
\hline 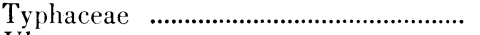 & - & 0.6 & 0.3 & - \\
\hline Ulmus & - & - & - & 0.2 \\
\hline Umbelliferae & - & 0.6 & 1.0 & 0.3 \\
\hline Viburnum & 0.3 & - & - & - \\
\hline Vitaceae & 2.4 & 3.3 & - & 0.3 \\
\hline 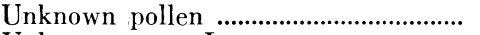 & 20.2 & 9.7 & 8.4 & 3.7 \\
\hline 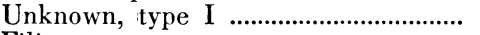 & 0.5 & 0.6 & - & 0.1 \\
\hline Filices & 3.7 & 6.7 & 2.6 & 1.0 \\
\hline 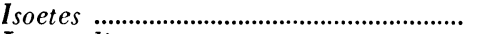 & - & 0.3 & - & - \\
\hline 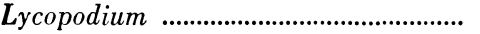 & - & 0.3 & 一 & 0.1 \\
\hline
\end{tabular}


TABLE 1 (Continued)

\begin{tabular}{|c|c|c|c|c|c|}
\hline \multirow[t]{2}{*}{ Pollen or spore type } & \multicolumn{5}{|c|}{ Percentage in sample } \\
\hline & $\mathrm{E}$ & $\underset{F}{\text { Varved }}$ & day $\mathrm{G}$ & Bog & $\begin{array}{l}\text { Sediment } \\
5.20 \mathrm{~m}\end{array}$ \\
\hline 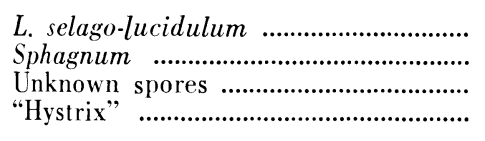 & $\begin{array}{l}- \\
1.6 \\
1.3 \\
0.5\end{array}$ & $\begin{array}{l}-\overline{3.3} \\
0.6 \\
-\end{array}$ & $\begin{array}{l}\overline{1.3} \\
- \\
-\end{array}$ & & $\begin{array}{l}0.2 \\
1.1 \\
0.1 \\
-\end{array}$ \\
\hline Number pollen and spores counted & $\begin{array}{r}100 \% \\
376\end{array}$ & $\begin{array}{r}100 \% \\
353\end{array}$ & $\begin{array}{r}100 \% \\
384\end{array}$ & & $\begin{array}{r}100 \% \\
894\end{array}$ \\
\hline
\end{tabular}

centages may be due to mistakes in identification, as well as to statistical error, as many of the pollen types found were unfamiliar to the author. Lower percentages of Betula and Quercus in sample E, however, may represent a real difference between this sample and the others.

Of particular interest is the occurrence in the varved clay of Platycarya, Pterocarya and Engelhardtia-Alfaroa pollen. Photomicrographs of these types are shown in plate 1, figs. 1-6, 9. Many of the pollen types in the clay are unlike those I have seen in Quaternary deposits in Massachusetts and are only tentatively identified or are listed as "unknown". Many of these unknown types were also observed in the bog sediments. For example, "Unknown, type I" (pl. 1, fig. 7) was found at 4.85, 4.90, 5.05 (2 grains), 5.10 (4 grains), 5.15 ( 2 grains), and $5.20 \mathrm{~m}$. This pollen is characterized by very heavy exine thickenings around the pores (colpae?) and appears similar to a pollen type found in upper Cretaceous and Eocene deposits and, as rebedded pollen, in postglacial marine clays in Sweden (Fries and Ross, 1950: cf. pl. 1, fig. 7) . A similar pollen type, "Unknown, type II" (pl. 1, fig. 8), appears identical to pollen known from upper Cretaceous and Paleocene sediments in Germany, and, as a rebedded fossil, in late- and postglacial marine clays in Sweden (Fries and Ross, 1950: cf. pl. 1, fig. 6). Several types of spherical microfossils with forked spines were found; one of these "Hystrix" types is shown in plate 1, figure 10. Similar microfossils are known from Cretaceous and Tertiary marine sediments in Europe, and have been reported in Quaternary tills and clays, where they apparently have been secondarily deposited (Iversen, 1936; Fries and Ross, 1950). "Hystrix" is thought to be a marine protozoan, but its exact affinities are unknown. It represents an extant form, as appears to be indicated by its occurrence in postglacial freshwater peat, near a contact with salt-marsh peat, at the John Hancock fishweir site at Boston, Massachusetts (Wilson, 1949).

Apparently some, and perhaps all, of the pollen in the varved clay has been rebedded from older deposits. As the ice in the immediate vicinity seems to have contained little if any pollen, the secondary pollen must have been carried from some distance, presumably by glacial meltwater. This conclusion is supported by studies of the stones in outwash deposits at Taunton, which indicate meltwater transport from the northeast (J. H. Hartshorn, personal communication). In addition to pollen derived from Tertiary (and Creta- 
3.

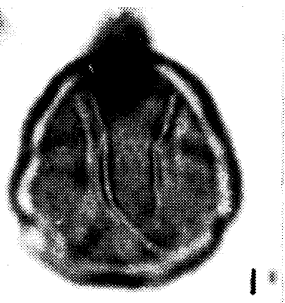

1 .

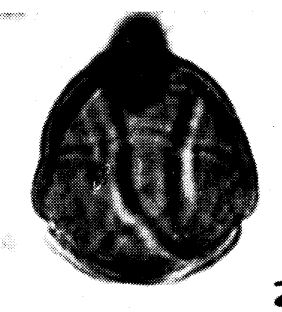

2

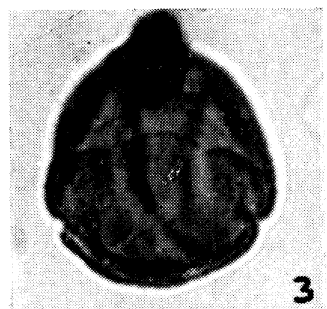

5

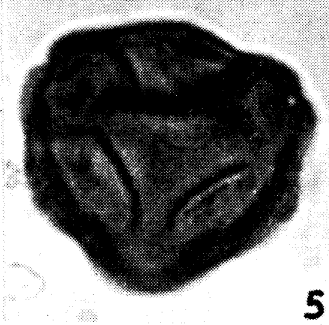

3

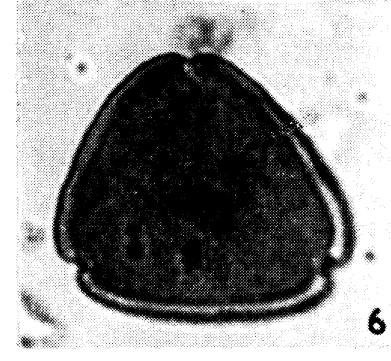

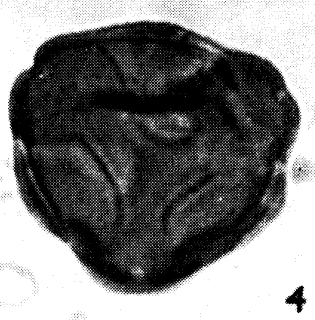

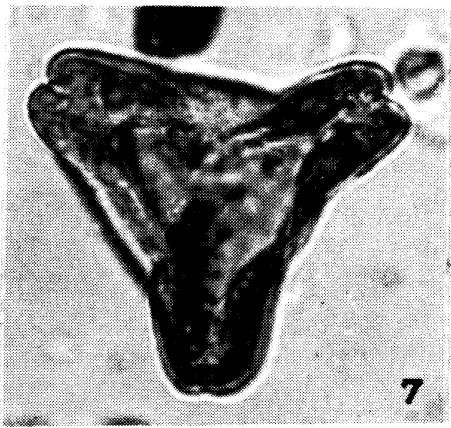

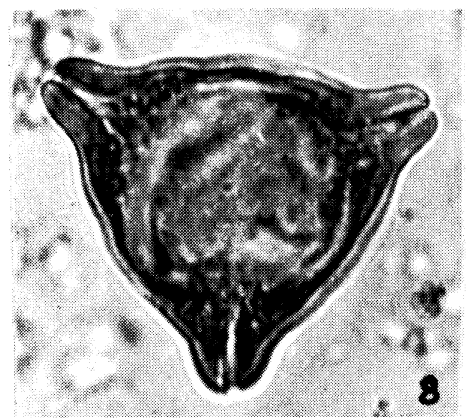
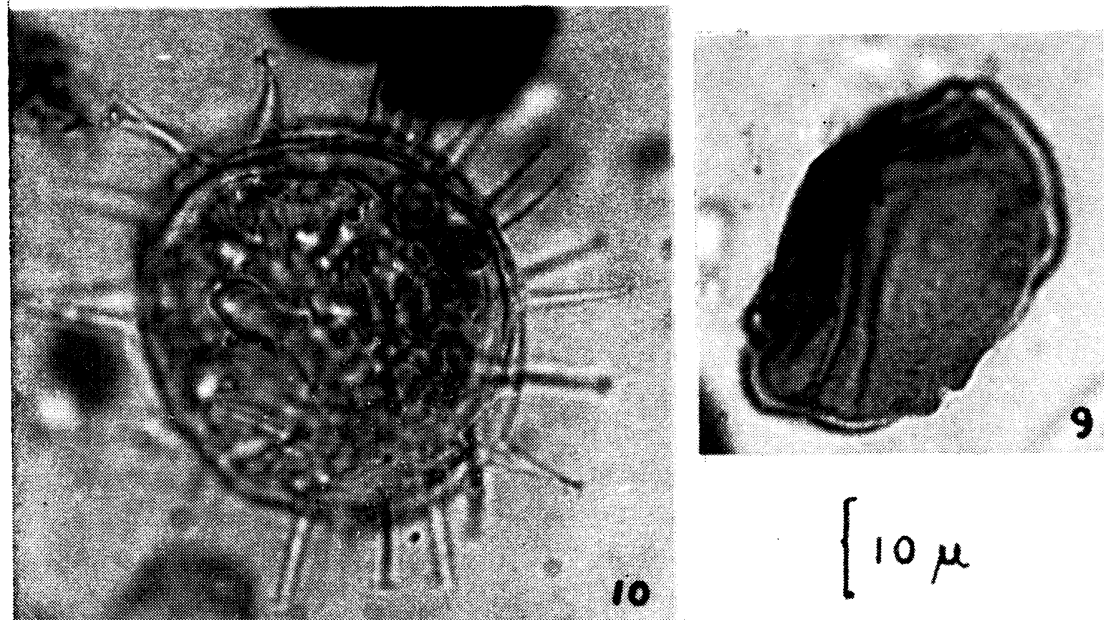

6 
ceous?) sediments, the meltwater may have transported pollen derived from interglacial and interstadial deposits that were eroded by the ice, and pollen from vegetation then growing some distance from Taunton. It is also possible that the varved clay contains primary pollen from plants growing within pollen dispersal distance of Taunton at the time the varved clays were deposited.

A previous investigation of the varved clays at Taunton (Hyyppä, 1955) led to quite different conclusions. Hyyppä identified pollen of twelve native tree genera in the varved clay. He assumed all the pollen was primary and considered the predominance of deciduous tree pollen evidence of deposition during an interstadial when a "southern deciduous climate" prevailed not far outside the margin of the glacier ice. On the basis of the occurrence of marine, brackish water and a few freshwater diatom species in the varved clay he concluded that the clay was deposited in a shallow marginal sea. However, I consider the presence of pollen of exotic genera, even though it occurs in low percentages, evidence that the clay is contaminated with rebedded microfossils. For this reason the microfossils are unreliable as vegetational and climatic indicators of the conditions that prevailed at the time the clay was deposited.

\section{DISCUSSION}

The sediments in the Williams Street bog apparently were contaminated with secondary pollen either through the erosion and redeposition of varved clay, or through the direct action of meltwater streams flowing into or over the site of deposition. The first of these hypotheses seems unlikely because the surface of the varved clay is at least 10 to $20 \mathrm{ft}$ lower than the esker and kame or lake deposits that surround the bog. However, it is conceivable that other outwash deposits (e.g. the kame deposits?) were eroded and redeposited as the ice block underlying the site of deposition melted. If these outwash deposits contained pollen from meltwater streams deposited contemporaneously with the pollen in the varved clay, the spectrum found in the varved clay would be similar to the spectrum of pollen deposited secondarily in the bog sediments. Even when these assumptions are made, however, it is still not possible to ap-

\section{PLATE 1}

Microfossils from varved clay sample $E$. The photomicrographs were all made with an oil immersion lens, and have been equally enlarged. Scale indicated in lower righthand corner of plate.

Figs. 1-3, Platycarya. Fig. 1, focus on upper surface of grain, Fig. 2, focus on optical cross section of pores, Fig. 3, focus on lower surface of grain.

Figs. 4-5, Platycarya-type ? Fig. 4, focus on optical cross section of pores, Fig. 5, focus on lower surface of grain.

Fig. 6, Engelhardtia-Alfaroa?, focus on wall, and optical cross section of pore in upper portion of photograph. This grain resembles cf. Engelhardtia pollen from the lateTertiary of Denmark (Ingwersen, 1958). Other grains seen resembled modern pollen more closely.

Fig. 7, "Unknown, type I", focus on surface of wall in upper left-hand portion of grain, showing pore (colpus?), and on optical cross section of upper right-hand pore, showing heavy exine thickenings.

Fig. 8, "Unknown, type II", focus on optical cross section of colpae, showing heavy exine thickenings.

Fig. 9, Pterocarya, focus on uppermost, folded portion of grain. Only one of the five pores is clearly in focus.

Fig. 10, "Hystrix", focus on two of the many forked spines. Other "Hystrix" types seen were larger, with heavier spines. 
ply Iversen's (1936) subtraction method. Iversen divided the secondary pollen spectrum into two groups: Group A included pollen of extinct Tertiary genera, and Group B included pollen which could not be distinguished from Quaternary pollen types. He demonstrated that the ratios of pollen types within Group A remained constant in late-glacial sediments, regardless of the total amount of Group A pollen present. Assuming, therefore, that the ratio of Group B pollen to Group A pollen had also remained constant, he subtracted pollen types belonging to Group $B$ in the ratio to Group $A$ in which they had occurred in the till. Group A pollen was also subtracted, and the remaining pollen was assumed to be of primary origin. This method cannot be used here because the pollen of exotic genera (Group A) occurs in low frequencies both at the bog and in the varved clay deposit; the ratio of Group B to Group A pollen cannot be calculated with statistical accuracy.

The sediments may also have been contaminated by a meltwater stream flowing over the site before the underlying ice had melted, or into the site after melting had begun. In this case the spectrum of pollen in the varved clay is not necessarily the same as the secondary pollen spectrum in the bog sediments, as the varved clay may contain both primary pollen, and secondary pollen brought in by other meltwater streams. Assuming the bog sediments were contaminated directly by glacial meltwater, they may be of the same age or only slightly younger than the uppermost levels of the varved clay deposit. If samples had been collected higher in the clay section, it might have been possible, by comparing the pollen spectra with those found in the lowest levels of the bog deposit, to test this hypothesis.

Direct contamination by glacial meltwater is in contrast to the mode of contamination described in Europe. In Denmark and Finland the boulder-clay is often rich in pollen (Iversen, 1936; Heinonen, 1957). Pollen and fine inorganic debris were apparently washed from the moraines and redeposited in lakes and ponds during periods of intense solifluction. Autochthonous, organic late-glacial sediments, deposited when slope-wash was not effective, are often entirely free of secondary pollen; usually the amount of contamination varies with the clay content of the sediments (Iversen, 1936, 1947; Krog, 1954). At Taunton, however, the erosion and redeposition of till and outwash deposited by local ice would not have resulted in extensive deposition of secondary pollen. If the deposition of secondary pollen depended upon meltwater streams, there is no necessary correlation between the amount deposited and the loss on ignition of the sediments, nor between the amount deposited and the severity of the climate.

As the spectrum of secondary pollen deposited in the bog sediments has not been determined with certainty, the spectrum of primary pollen remains unknown. Mixed primary and secondary pollen spectra are meaningless-they represent vegetation that never existed at a point in time, and vegetational interpretations cannot be attempted. Above the 4.52-m level, however, pollen of Platycarya, Pterocarya, Engelhardtia-Alfaroa and "Unknown, type I" were not found. The sediments above $4.52 \mathrm{~m}$ may be free, or nearly free, of contamination, and a vegetational interpretation based on the major constituents can be made with reasonable confidence. 


\section{CONCLUSIONS}

The problems of identifying secondary pollen and estimating the extent of contamination are obviously difficult even when a considerable amount of data is at hand. Subtraction of secondary pollen is possible only when the complete spectrum is known from the source materials, and when the recognizable secondary types (such as exotic genera) occur in frequencies sufficient to permit subtraction by Iversen's (1936) method with statistical accuracy. Supposed ecological incompatibility of plants represented in the pollen spectrum is not a sufficient criterion for the recognition of secondary pollen, because: (1) the latter may include a variety of pollen types from deposits of different ages, (2) it may not represent a community distinguishable from late-glacial vegetation (Donner. 1957). and (3) the late-glacial vegetation itself may have been made up of species which do not occur together today (Drury, 1956; Benninghoff. 1957). Even if two distinct communities are recognized within the pollen spectrum. choice of one of them as primary and the other as secondary involves a preconception on the part of the investigator. Where there is evidence of contamination, but no way of estimating its nature or extent, pollen investigators might better abandon attempts at interpretation than run the risk of reaching erroneous conclusions.

\section{REFERENCES}

Andersen, S. T., 1954, A late-glacial pollen diagram from southern Michigan, U. S. A.: Danmarks geol. Undersøgelse, raekke II, no. 80, p. 140-155.

Benninghoff, W. S., 1957, Interglacial and late-glacial vegetation of the north-central United States: Geol. Soc. America Bull., v. 68, p. 1888.

Davis, M. B., 1958, Three pollen diagrams from central Massachusetts: Am. Jour. Sci, v. 256 , p. $540-570$.

1960, A late-glacial pollen diagram from Taunton, Massachusetts: Torrey Bot. Club Bull., v. 87, p. 258-270.

Donner, J., 1957, The late-glacial period and its correlation with the retreat stages of the ice in Finland: Comm. géol. Finlande Bull., no. 180 (Suomen Geol. Seura N:o 30), p. $79-86$.

Drury, W. H., 1956, Bog flats and physiographic processes in the Upper Kuskokwim River Region, Alaska: Gray Herbarium Contr. 178, $130 \mathrm{p}$.

Emerson, B. K., 1898, Geology of Old Hampshire County, Massachusetts, comprising Franklin, Hampshire, and Hampden Counties: U. S. Geol. Survey Mon. 29, 790 p. $597,289 \mathrm{p}$.

Flint, R. F., and others, 1959, Glacial map of the United States east of the Rocky Mountains: Geol. Soc. America special map.

Frey, D. G., 1951, Pollen succession in the sediments of Singletary Lake, North Carolina: Ecology, v. 32, p. 518-533.

Fries, Magnus, and Ross, N.-E., 1950. Pre-Quaternary pollen grains and spores found in late-glacial and post-glacial claỵs in Bohuslän, SW. Sweden: Arkiv för Mineralogie och Geologie, v. 1. p. 199-210.

Hartshorn, J. H., 1958, Flowtill in southeastern Massachusetts: Geol. Soc. America Bull., v. 69, p. $477-182$.

Heinonen, L., 1957, Studies on the microfossils in the tills of the North-European glaciation: Acad. Sci. Fennicae Annales, ser. A, III, 52, 92 p.

Hyyppä, E., 1955, On the Pleistocene geology of southeastern New England: Comm. géol. Finlande Bull., no. 167, p. 155-225.

Ingwersen, P., 1958, Some microfossils from Danish late-Tertiary lignites: Danmarks geol. Undersøgelse, raekke II, no. 80, p. 31-64.

Iversen, J., 1936, Sekundäres Pollen als Fehlerquelle: Danmarks geol. Unders $\varnothing$ gelse, raekke IV, no. 15 , p. 3-24.

1947, Plantevaekst, dyreliv og klima i det senglaciale Danmark: Geol. fören. Stockholm Förh., v. 69, p. 67-78. 
Krog, H., 1954, Pollen analytical investigation of a $\mathrm{C}^{14}$-dated Alleröd-section from RudsVedby: Danmarks geol. Undersøgelse, rekke II, no. 80, p. 120-139.

LaMotte, R. S., 1952, Catalogue of the Cenozoic plants of North America through 1950: Geol. Soc. America Mem. 51, 381 p.

Leopold, E. B., 1955, Climate and vegetation changes in southern Connecticut during the Two Creeks interstadial: Unpub. Ph.D. Thesis, Yale University.

1956, Two late-glacial deposits in southern Connecticut: Natl. Acad. Sci. Proc., v. 42, p. 853-857.

Leopold, E. B., and Scott, R. A., 1958, Pollen and spores and their use in geology: Smithsonian Inst. Rept. 1957, p. 303-323.

ms., On the occurrences of Platycarya pollen in the North American Tertiary.

Livingstone, D. A., and Livingstone, B. G. R., 1958, Late-glacial and postglacial vegetation from Gillis Lake in Richmond County, Cape Breton Island, Nova Scotia: Am. Jour. Sci., v. 256, p. 341-359.

Martin, P. S., 1.958, Taiga-tundra and the full-glacial period in Chester County, Pennsylvania: Am. Jour. Sci., v. 256, p. 470-502.

Mather, K. F., Goldthwait, R. P., and Thiesmeyer ,L. R., 1942, Pleistocene geology of western Cape Cod, Massachusetts: Geol. Soc. America Bull., v. 53, p. 1127-1.174.

Ogden, J. G., III, 1959, A late-glacial pollen sequence from Martha's Vineyard, Massachusetts: Am. Jour. Sci., v. 257, p. 366-381.

Sayles, R. W., and A. S. Knox, 1943, Fossiliferous tills and intertill beds of Cape Cod, Mass.: Geol. Soc. America Bull., v. 54, p. 1569-1612.

Wilson, L. R., 1949, A microfossil analysis of the lower peat and associated sediments at the John Hancock fishweir site: Robert S. Peabody Found. Archaeology Papers, The Boylston Street Fishweir II, v. 4, p. 84-98. 